\title{
THE IMPACT OF RELATIONAL VALUE TOWARDS CUSTOMER BRAND RELATIONSHIP STICKINESS IN THE CONTEXT OF MALAYSIAN PUBLIC HIGHER EDUCATION SERVICE
}

\author{
Sharizal Hashim* \\ Universiti Malaysia Sarawak \\ Norjaya Mohammed Yasin \\ Prince Sultan University
}

\begin{abstract}
This study attempts to investigate the effects of customer value specifically the relational value towards customer brand relationship stickiness in Malaysian public higher education service. Investigating relational value is crucial because it has transpired as one of the basic operant resources of customer value in the service co-creation and contributed in the success of customer brand relationship. Using proportionate stratified random sampling, questionnaires were distributed to 701 postgraduate students studying in the Business and Social Science fields in the Malaysian public universities. The reliability of all the constructs tested produced satisfactory coefficients. Multiple regression and Partial Least Square (PLS) bootstrapping procedures were conducted. The findings support the Social Exchange Theory and previous body of research that indicate positive and significant relationships between customer value such as utility value, hedonic value and relational value including customer brand relationship stickiness pertinent to brand relationship quality and brand resonance. In addition, customer relationship stickiness with the service brand is largely dependent on the motivation of exchanging relational values compared to other customer value dimensions such as utility value and hedonic value. This indicates that relational values such as trust, bonding, empathy and mutual dependence are the key elements in the branding process of the service organisation. For this reason, the success of a service can only be achieved through a strong relationship between customers and the brand of the service. Therefore, this paper offers evidence of the association concerning relationship perspective in the social exchange theory. The contribution of this study is an effort to expand customer brand relationship knowledge particularly in the service domain.
\end{abstract}

Keywords: Customer Brand Relationship; Customer Value; Brand Relationship Quality; Brand Resonance; Social Exchange Theory; Malaysian Public Higher Education.

\section{INTRODUCTION}

In order to strengthen the role of branding in driving organisational survival, few scholars have integrated brand with other prominent marketing concepts such as relationship marketing and customer brand relationship (Blackston \& Lebar, 2015; Fournier et al., 2008; Breivik \& Thorbjørnsen, 2008). The introduction of such integrated concept is substantial because the establishment of a strong relationship between the customer and the brand is able to provide better value to the organisational structure and capability to compete (Blackston \& Lebar, 2015; Hu et al., 2011), and as a better measure of marketing

-Corresponding Author: Faculty of Business and Economics, Universiti Malaysia Sarawak, Kota Samarahan, Sarawak, Malaysia. Tel.:+6082-584302 Email: hsharizal@unimas.my 
success and business effectiveness (Dowling, 2002; Smit et al., 2007). Shimp and Madden (1988) were the first to propose the concept of the relationship between customers and brand by using the logic extension of the interpersonal relationship metaphor. Subsequently, several marketing scholars extended the effort of Shimp and Madden, such as the relationship metaphor by Aaker (1997), interpersonal metaphor (Fournier, 1998), social norms (Aggarwal, 2004) and customer brand relationship segmentation (Story \& Hess, 2006).

However, there is an issue that needs further investigation, such as the determinants of customer brand relationship especially in the context of service. According to past literature, most marketing scholars agreed that customer value is an important determinant of customer response towards a product or services (Oh \& Teo, 2010; Sheth, Sethia, \& Srinivas, 2011; Vargo \& Lusch, 2004; Vargo et al., 2008). This is consistent with the Social Exchange Theory (SET), which posited that customer behaviour is driven by the motivation of an exchange of value or benefits (Zafirovski, 2005). However, in the context of customer brand relationship, previous scholars focused more on utilitarian value or quality (Parasuraman, Zeithaml \& Berry, 1985) and hedonic value or brand equity (Berry, 2000; Chiu et al., 2012; Sharizal \& Norjaya, 2012); but studies in the past neglected the relational value in the overall customer value construct that influences customer response towards a brand.

Consideration of relational value as the additional determinant is crucial because according to Eiriz and Wilson (2006) and Brodie, Gylnn and Little (2006), relational value is able to enhance the "stickiness" of the relationship between customer and brand, especially in the service context. On that account, utility and hedonic values have limitations in differentiating how customers perceive and evaluate brands beyond the monetary evaluation. However, the statement highlighted by Eiriz and Wilson (2006) and Brodie et al., (2006), is still lacking of empirical evidence pertaining to the impact of relational value towards the concept of brand relationship stickiness. Therefore, the focus of this study is to investigate the impact of relational value in the overall customer value construct towards customer relationship stickiness with the brand specifically in the context of service.

On the other hand, one of the service categories that received much attention by recent service and branding researchers is the higher learning service (Chapleo, 2011; Wæraas \& Solbakk, 2009). This was owing to the increase number of higher learning services or universities domestically and internationally. As a result, management of universities had to rely on branding in order to differentiate themselves (Hemsley-Brown \& Goonawardana, 2007) and this heavy reliance on branding gradually allowed educational learning service to emerge. Educational related learning service is one of the service categories that captures the fundamental function of the service-dominant view in which intangibility, exchange processes and relationships are central (Vargo \& Lusch, 2004; Zainuddin et al., 2011).

Efforts investigating branding in the context of higher learning service related to discussion associated with branding policies in general (e.g., Goi \& Goi, 2009; Judson, Aurand \& Gorchels, 2006; Teh \& Aliah Hanim, 2011) or focus on the external aspects of branding are scanty. Particularly aspects linked to communication effectiveness (Klassen, 2002), corporate identity (Melewar \& Akel, 2006), student satisfaction (Balwin \& James, 2000) and student perceived value (Brown \& Mazzarol, 2009) are least investigated research focus in the past studies. However, such efforts are contestable because the investigation of relational value element in student's brand perspective as the customer is relatively nebulous despite the necessity it demands in recent social economic perspective (Chapleo, 2011). In this respect, Hemsley-Brown and Oplatka (2006) suggest that relationship elements are feasible and practical strategies for higher education as effective branding strategy in the business world. Thus, to contribute to a more tolerant way of branding in higher learning service, recent branding issue such as 
brand relationship stickiness that are linked to the modern and creative branding approach especially relational brand perspective will be the focus of this study.

\section{LITERATURE REVIEW}

Theoretically, the customer brand relationship is characterised as the relationship between a person and a brand just like a human relationship (Blackston \& Lebar, 2015). This phenomenon is insightful because, according to Fournier, Solomon, and Englis (2008), the brand is able to serve as a relationship partner with the customer from the way the brand is animated, humanised and personalised. Moreover, few studies posited that customers show no difficulty in assigning personality qualities to inanimate objects including the brand (Keller, 2001; Sweeney \& Chew, 2002; Hess \& Story, 2005). The customer brand relationship concept has also received attention from the business perspective, especially in the context of service. This is due to its intangibility and complex nature, which makes dependency on the proper treatment of relationship building a vital cornerstone for the success of the service (Nyffenegger et al., 2015). In line with Service-Dominant (S-D) logic perspective, managing the customer-brand relationship is important in services because the success of service can only be achieved through a strong relationship between the customer and the brand of the service (Vargo \& Lusch, 2004; Klaus \& Maklan, 2007). Besides, S-D logic perspective also recognized the importance of brand in service value cocreation. According to Merz, He, and Vargo (2009), the brand becomes an important 'off-balance sheet' asset and a sign system that symbolizes the market value processes of the service industry. Specifically, the brand becomes the source of customer experience in the service co-creation process which later creates value in the relationship between the customer and the service provider.

\section{1. $\quad$ The Importance of Customer Value in Service Branding}

From the service-dominant (S-D) logic point of view, customer value is important for the 'market system' especially for service brand to be successful (Sheth, Sethia, \& Srinivas, 2011). The perceived brand value of a service is determined by the customer on the basis of value-in-use through the dynamic interaction of the customers to co-create the service (Oh \& Teo, 2010). Besides that, based on behaviorist perspective, fulfilling customer value is the reason and stimulus for customers to behave positively in the interaction. The customer tends to invest more in their relationship with a firm that can deliver superior value relative to the offerings of others (Vargo \& Lusch, 2008). This is also consistent with the Social Exchange Theory, which posited customer reciprocal behavior is driven by the motivation of an exchange of value/benefits (Zafirovski, 2005). If a service provider is able to provide value to meet customers' expectations, as equitable outcome, the customer will favorably reciprocate with the service provider. Thus, by understanding customer value an immediate clue or information about what to be emphasized in order to develop a good brand relationship with the customer will become lucid.

Customer value is defined as the customer's overall assessment of the performance of a product or service, based on perception of what is received and what is given (Zeithaml, 1988). However, customer value should not be viewed as the simple outcome of a trade-off between quality or utility and sacrifice, because the customer value is complex in nature. Furthermore, customer value that is limited to the utility of a product/service and hedonic aspect, does not fit with the service co-creation concept that requires an additional aspect, such as interaction or relational value (Khan, 2010). 
Considering relational value as another determinant in the magnification of recent brand relationship discussion is consistent with the Customer Equity concept by Rust, Lemon and Zeithaml, (2004). Value equity (utility value), brand equity (hedonic value), and relationship equity (relational value) are three drivers which will exert an influence on customer behavior as highlighted by the authors. In addition, these drivers have also been acknowledged as important elements in understanding the description of recent service domain. Referring to Brodie, Glynn and Little (2006), the service-centered view perceives that every person has three basic parent resources comprising physical (utility), mental skill (hedonic) and social (relational) which is grounded in the Resource Advantage Theory and Core Competency Theory.

\subsubsection{Utility Value}

According to Sheth et al., (2011), the maximization of customer value becomes the superordinate of the customer goal, because, without it, there will be little motivation for the customers to make repeat purchases. One aspect of customers' value maximization is the intrinsic and extrinsic utility value (Sánchez et al., 2006). Rust et al. (2004) conceptualized utility value, or termed as value equity, as the customer's objective assessment of the utility of a brand based on the perception concerning what is given up for what is received. They also operationalized the service utility value, as consisting of three components - quality, price and convenience (Seiders et al., 2007).

\subsubsection{Hedonic Value}

In an attempt to conceptualize the hedonic value towards the brand, the marketing literature discusses the term "brand equity", which can be divided into brand strength and brand value (Becker-Olsen \& Hill, 2006). According to Sloot et al. (2005), the brand strength and brand value approaches generally share basic premises about the brand, which lies in the customer hedonic value perspective and interpretation. This perspective and interpretation depends on the overall superiority experience, hedonic feelings and learning about the brand over time (Sa'nchez et al., 2006). Berry (2000) introduced a specific brand equity concept in service consisting of brand awareness and brand meaning as the value added construct that deals with the issue of intangibility and credence attributes of the service. Berry's service brand equity model is also viewed to be more effective in enhancing positive customer hedonic value because the model explicitly plays with the emotional motives of the customer buying process (Norbani \& Sharizal, 2007; Sloot, Verhoef, \& Franses, 2005).

\subsubsection{Relational Value}

Rust, Lemon and Zeithaml (2004) conceptualized relational value as the tendency of the customer to stay with the brand, above and beyond the customer's objective (utility) and subjective assessment (hedonic) of the brand. On the other hand, Ulaga and Eggert (2005) conceptualized relational value as how customers assess their social benefits and effectiveness of the working relationships with one supplier relative to alternative suppliers. However, the relationship equity, as proposed by Rust et al., (2004), faces a limitation in operationalizing the essence of the heterogeneous and equivocal construct of the relational value. It would seem that the drivers of relationship equity namely loyalty programs, affinity programs, community building programs and knowledge building programs faces an operationalized ambiguity because they are more akin to the brand programs for the existing customers rather than direct operational definition for the customer's relational value construct (Leone et al., 2006). 
Alternatively, the introduction of the relational attitude concept as the basic component of a relationship marketing orientation by Konovsky and Pugh (1994), and later extended by Yau et al. (2000), offers a more direct description of the relational value constructs. The concept was originally used to explain why employees exhibit loyalty to the organization and to engage in behaviour is extended to the explanation of how to establish reciprocal relationships in the modern social economic context. Yau et al. (2000) operationalized customer's relational value as trust, bonding, mutual dependence, and empathy.

\subsection{Customer-Brand Relationship Stickiness}

Thus far, customer stickiness is among the main research agenda in marketing (Kumar, Lassar, \& Butaney, 2014). According to Khalifa, Limayem and Liu (2002), high customer brand stickiness can substantially reduce marketing and customer retention cost in the long run. Customer stickiness has also become more important in the commercial setting that has a wide variety of choices and global competitions such as cyberspace and brand (Polites et al., 2012; Brodie et al., 2013). Referring to the literatures such as Polites et al. (2012) and Li et al. (2006), the general concept of customer stickiness is about the nebulous criterion of customer's psychological tie and positive brand behavior. In this respect, branding scholars associate customer's psychological tie as brand relationship quality (Shimp \& Madden, 1988; Morgan \& Hunt, 1994; Fournier, 1998; Kim, Park \& Kim, 2014), while brand resonance as positive brand behavior (Keller, 2008; Huang et al., 2014).

\subsubsection{Brand Relationship Quality}

Brand relationship quality can best be defined as the customer's perception and impression concerning how well the brand fulfills the psychological nature of the customer (Rauyruen \& Miller, 2007; Yim, Tse, \& Chan, 2008). Moreover, according to Kim et al. (2014), brand relationship quality (BRQ) is a much richer concept of customer brand psychological evaluations because it provides a better description of what it means by strong and durable consumer-brand relationships. Underpinned by Sternberg's (1986) triangular theory of love, Shimp and Madden (1988) proposed brand relationship quality contains three parallel psychological dimensions which are liking (intimacy), yearning (passion), and decision (commitment). Breivik and Thorbjørnsen (2008) further claimed that the refinement of the BRQ model underpinned by Sternberg's (1986) triangular theory of love consists of commitment, yearning and liking are able to explain the meaning of relationship quality and psychological tie between customers and brands.

\subsubsection{Brand Resonance}

Keller (2008) defined brand resonance as the nature of the brand relationship outcome and positive behavior to which customers feel that they are "in sync" with the brand (Huang et al., 2014). Keller (2008) operationalized it as behavioral and attitudinal loyalty, together with sense of community and active engagement. Kuhn, Alpert and Pope (2008) also conceptualized Keller's brand resonance as the 'intensity' that the customer has with the brand. Furthermore, 'intensity' issue and brand resonance are also in line with the recent service perspective of S-D logic discussion. Referring to the literature, service co-creation success depends on the customer's relationship intensity with the service brand and stay with the service organization (Vargo \& Lusch, 2004; Merz et al., 2009). In addition, few studies posited brand resonance as the valuable tool to understand the relationship outcome in service brand fields such as Norjaya and Norzalita (2010) in banking and Sharizal and Norjaya (2012) in telecommunication. 


\section{HYPOTHESIS DEVELOPMENT}

The Social Exchange Theory (SET) elucidates the issue of customer reciprocity perspective in the recent social, economic and relationship discussion (Eiriz \& Wilson, 2006; Hu et al., 2011). Apart from supporting the understanding of dynamics involved in relationship, this theory also aids to determine the methodological difficulties faced by the organization towards managing their relationship in the exchange behaviour with their customers. Pertaining to the explanation of brand relationship reciprocity issues, strong psychological ties and positive brand behavior response by the customer, SET assumes that the influence depends on the multiple stimuli of value or benefits (Hinde, 1995; Cook \& Emerson, 1987; Zafirovski, 2005). The assumption is also in line with empirical evidences that supports the notion of customer values impact such as service quality-commitment (see Roberts et al., 2003), hedonicpsychological tie (see Broyles et al., 2009), relational value- psychological tie (see Zainuddin et al., 2011), quality and relational value-positive behavior (see Vogel et al., 2008) and hedonic value-positive behavior (see Chiu et al., 2014). In addition, Grönroos and Gummerus (2014) also recommended that future researchers need to look into multidimensional value perception to understand the dynamic nature of value creation in service and brand.

Alves and Raposo (2007) postulated the importance of student's perception of value towards their overall education experiences in the higher education context. Focussing on student's values as their target market is essential for the institutions to stay competitive in the industry (Verghese \& Kamalanabhan, 2015). When describing value in the context of higher education experience, multidimensional treatment is required (Alves \& Raposo, 2007). Students not only consider the functional aspect (utility value) but also the symbol, enjoyment (hedonic value) and social aspect (relational value) (Sheth et al., 1991; Vargo \& Lusch 2004). Besides that, understanding how student's value perceptions arise will lead to positive results in higher levels of loyalty and word of mouth (Gallarza, Gil-Saura, \& Holbrook, 2011). However, there are limited studies which investigate the association of student's value perceptions towards brand reciprocity result principally based on brand stickiness. According to Lambe, Wittmann and Spekman (2001), and Zafirovski (2005), customer values are capable to influence customer's psychological tie and behaviour towards a brandThis study presumes that higher education is also affected by the same nature. Therefore, the study hypothesizes the multiple stimuli of student's values such as utility, hedonic and relational values have a significant effect towards their brand stickiness (brand relationship quality and brand resonance) of their higher education institution. Figure 1 depicts the path of variables tested in the study.

Figure 1: Customer Value and Brand Relationship Stickiness

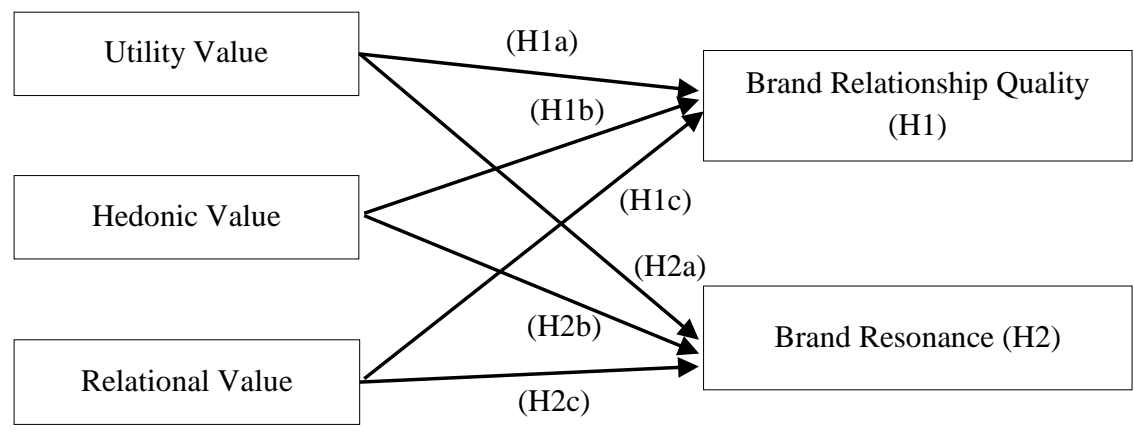


H1: Customer values have a significant effect on brand relationship quality

Hla: Utility value has a significant effect on brand relationship quality

$H 1 b$ : Hedonic value has a significant effect on brand relationship quality

$H 1 c$ : Relational value has a significant effect on brand relationship quality

$H 2$ : Customer values have a significant effect on brand resonance

$H 2 a$ : Utility value has a significant effect on brand resonance

$H 2 b$ : Hedonic value has a significant effect on brand resonance

$H 2 c$ : Relational value has a significant effect on brand resonance

Relational value received less attention by previous scholars towards conceptualizing the overall value construct that may influence how customer response with a service brand. Nevertheless, the discussion about the underlying value of customer brand relationship need further investigation in respect of its application in a service brand context. According to Eiriz and Wilson (2006), considering relational values as another element in the overall value construct is crucial because the utility and hedonic value constructs have limitations in examining the differences in how customers perceive and evaluate brands beyond the monetary evaluation. Grönroos and Gummerus (2014) asserted that relational value perspective is the main reason which projects the distinctiveness in service branding compared to conventional goods-based models. In this respect, Brodie et al. (2006) and Merz et al. (2009) claimed that, inclusion of relational value as another basic operant resource of service co-creation, serves as the best way to "glue" customers to the service firm and enhance the "stickiness" of the relationship experience. However, there is still a lack of empirical evidence that support Brodie et al. (2006) and Merz et al. (2009) claim.

In the context of higher education, Gibbs (2002) and Hemsley-Brown and Oplatka (2006) suggests that educational achievement should be seen as a collaborative perspective that focus on humanistic and relational value, rather than performing transactional deals with their students. Hence, this study considers there is considerable space for future research emphasising the intensity of a relational value effect towards student's brand response in particular the brand stickiness because it is emerging as the key to unlocking new sources of competitive advantage (Prahalad \& Ramaswamy, 2004). Besides that, exploring the brand relationship stickiness is important to provide a holistic description of customer brand relationship phenomena (Brodie et al., 2006; Grönroos \& Gummerus, 2014). Therefore, this study hypothesizes that there is a significant effect towards relationship quality and brand resonance prediction as resulted from the occurrence of relational value in the overall student's value construct.

H3: Inclusion of relational value alongside with utility and hedonic value has a significant effect on brand relationship quality prediction.

H4: Inclusion of relational value alongside with utility and hedonic value has a significant effect on brand resonance prediction.

\section{METHODOLOGY}

This study used reflective-formative measurement model as depicted in Table 1. But, the measurement items are adjusted based on the feedback obtained from the experts and pre-test of 10 colleagues in the business and economics doctoral programme from the University Kebangsaan Malaysia in order to adequately capture the Malaysian higher education service context. This was followed by a set of self- 
administered questionnaires was developed using the adjusted multi-item indicators with alternatives of a 5-point Likert scale ranging from strongly disagree (1) to strongly agree (5).

Table 1: Measurement Summary

\begin{tabular}{clc}
\hline \hline Construct & \multicolumn{1}{c}{ Measurement/Sources } & Alpha/Item(s) \\
\hline Utility Value & Quality (Cronin, Brady, \& Hult, 2000) & $0.93 / 4$ items \\
& Price (O'cass \& Grace, 2004) & $0.91 / 3$ items \\
& Convenience (Seiders et al., 2007) & $0.89 / 3$ items \\
\hline \multirow{2}{*}{ Hedonic Value } & Brand Awareness (Norjaya \& Norzalita, 2010) & $0.92 / 4$ items \\
& Brand Meaning (Vogel et al. (2008) & $0.85 / 4$ items \\
\hline Relational Value & Trust (Chaudhuri \& Holbrook, 2001) & $0.81 / 4$ items \\
& Bonding (Yau et al., 2000) & $0.85 / 3$ items \\
& Mutual dependence (Yau et al., 2000) & $0.78 / 3$ items \\
& Empathy (Yau et al., 2000) & $0.76 / 3$ items \\
\hline Brand Relationship Quality Commitment (Wu, 2011) & $0.92 / 4$ items \\
& Yearning (Breivik \& Thorbjørnsen, 2008) & $0.84 / 4$ items \\
& Liking (Wojciszke, Abele, \& Baryla, 2009) & $0.80 / 4$ items \\
\hline Brand Resonance & Behavioural loyalty (Chaudhuri \& Holbrook, 2001) & $0.88 / 3$ items \\
& Attitudinal loyalty (Fullerton, 2005) & $0.97 / 3$ items \\
& Sense of community (Norjaya \& Norzalita, 2010) & $0.90 / 3$ items \\
& Active engagement (Norjaya \& Norzalita, 2010) & $0.90 / 4$ items \\
\hline \hline
\end{tabular}

A pilot study was conducted by distributing questionnaires to 50 business postgraduate students from the University Malaysia Sarawak to check the degree of reliability and validity of the questionnaire. Cronbach's alpha and exploratory factor analysis were used to assess the internal consistency and validity of the five constructs using SPSS Version 24. The alpha values ranged from 0.839 to 0.91 for the five constructs. In addition, the varimax rotation of the lower order items of the five constructs exceeded the suggested value of 0.60 Kaiser-Meyer-Olkin values and eigenvalues above 1 (Tabachnick \& Fidell, 2007). However, 1 item for utility value and hedonic value were excluded from the from the final study due to cross-loading of 0.40 and higher (Hair et al. 2010). In general, all the lower order items were significant to represent the meaning of the five constructs as discussed in the literature review.

\section{DATA COLLECTION}

This study focuses on postgraduate students studying in the Malaysian public higher institutions which represent $87 \%$ of the population of Malaysian postgraduate enrollment (MOHE, 2010). However, due to time and cost constraints, proportionate stratified random sampling was applied which limited the number of postgraduate students to the minimum of 664 from Business, Social Science and Law courses for the purpose of this study. These courses have higher student enrollment as opposed to other courses (Appendix 1). A total of 701 out of 750 (93\%) questionnaires were received, which exceeded the minimum sample required for data analysis. Table 2 illustrates the proportion of the sample of respondents which was consistent with the target percentage of the population across the seven leading institutions that represent $50 \%$ of the population of Malaysia postgraduate enrollment (Appendix 2). An analysis of the respondents' demographics is illustrated in Table 3 which reveals that 61 per cent were female. The highest age group was those between 21 to 30 years old $(70.6 \%)$ while $76.6 \%$ were enrolled for master's degree. With respect to the respondents' nationalities, $83 \%$ were Malaysians and the rest were foreigners. In terms of mode of study, $84.9 \%$ were studying on a full-time basis. 
Table 2: Sample Details

\begin{tabular}{|c|c|c|c|c|c|c|c|c|}
\hline \multirow{2}{*}{ Public HEI } & \multicolumn{5}{|c|}{ Years } & \multirow{2}{*}{ Total } & \multirow{2}{*}{ \% Samples } & \multirow{2}{*}{$\begin{array}{c}\% \text { in } \\
\text { Population }\end{array}$} \\
\hline & 1 & 2 & 3 & 4 & 5 & & & \\
\hline UPM & 24 & 54 & 39 & 4 & 6 & 127 & $18.12 \%$ & $18.21 \%$ \\
\hline UM & 41 & 31 & 37 & 8 & 3 & 120 & $17.12 \%$ & $17.30 \%$ \\
\hline UKM & 37 & 40 & 37 & 6 & 3 & 123 & $17.55 \%$ & $16.38 \%$ \\
\hline USM & 39 & 31 & 18 & 11 & 0 & 99 & $14.12 \%$ & $14.29 \%$ \\
\hline UTM & 22 & 27 & 18 & 12 & 7 & 86 & $12.27 \%$ & $12.27 \%$ \\
\hline UUM & 18 & 36 & 5 & 10 & 3 & 72 & $10.27 \%$ & $10.85 \%$ \\
\hline UiTM & 6 & 54 & 7 & 4 & 3 & 74 & $10.56 \%$ & $10.71 \%$ \\
\hline Total & 187 & 273 & 161 & 55 & 25 & 701 & & \\
\hline
\end{tabular}

Table 3: Respondent Profile

\begin{tabular}{|c|c|c|c|c|c|c|c|c|c|c|c|c|c|}
\hline \multirow[b]{2}{*}{ 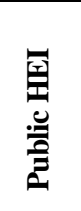 } & \multicolumn{2}{|c|}{ Level } & \multicolumn{2}{|c|}{ Gender } & \multicolumn{4}{|c|}{ Age } & \multicolumn{2}{|c|}{ Mode } & \multicolumn{2}{|c|}{ Nationality } & \multirow[b]{2}{*}{ हే } \\
\hline & 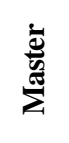 & 主 & $\sum_{\sum}^{\frac{0}{J}}$ & 莺 & $\frac{\text { ఢి }}{\stackrel{1}{n}}$ & $\frac{P}{\dot{p}}$ & $\underset{⿱ 乛}{\not}$ & 公 & & 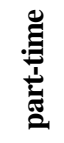 & $\sum^{\tilde{\Xi}}$ & 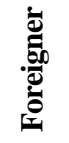 & \\
\hline UPM & 108 & 19 & 49 & 78 & 96 & 22 & 9 & 0 & 124 & 3 & & & 127 \\
\hline $\mathrm{UM}$ & 83 & 37 & 49 & 71 & 57 & 50 & 10 & 3 & 87 & 33 & & & 120 \\
\hline UKM & 90 & 33 & 47 & 76 & 75 & 26 & 22 & 0 & 100 & 23 & & & 123 \\
\hline USM & 75 & 24 & 36 & 63 & 86 & 12 & 1 & 0 & 88 & 11 & 582 & 119 & 99 \\
\hline UTM & 71 & 15 & 40 & 46 & 58 & 26 & 2 & 0 & 72 & 14 & & & 86 \\
\hline UUM & 53 & 19 & 25 & 47 & 59 & 9 & 4 & 0 & 55 & 17 & & & 72 \\
\hline UiTM & 57 & 17 & 28 & 46 & 64 & 6 & 4 & 0 & 69 & 5 & & & 74 \\
\hline Total & 537 & 164 & 274 & 427 & 495 & 151 & 52 & 3 & 595 & 106 & & & 701 \\
\hline
\end{tabular}

\section{RESULTS}

\subsection{Assessment of the Measurement Model}

The data were analyzed using the Partial Least Squares (PLS) procedures. The overall reliability coefficient for the instrument is 0.922 and exceeded the minimum $\alpha$ value, 0.7 (Hair et al., 2014). In detail, the KMO's measure of sampling adequacy for Utility Value is $0.849,0.871$ for Hedonic value, 0.878 for Relational Value, 0.906 for Brand Relationship Quality and 0.889 for Brand Resonance. All these values are greater than 0.70 , which is the satisfactory level recommended by Hair et al. (2010). Meanwhile, for the quality of the instrument, Hair et al. (2014) proposed three assessments namely measurement model's convergent validity, collinearity and total effect. As summarized in Table 4 and 5 , the convergent validity of the constructs tested in the study exceeded 0.70 path values, where Chin (1998) described as significant in the social science discipline. While, in terms of collinearity, the constructs exceed the VIF accepted value of $>1$ and tolerance accepted value of $<1$ (Hair et al., 2014). The total effects of the constructs exceeded 1.96 t-value and are significant at $5 \%(\alpha=0.05$; two-tailed test) through PLS's bootstrapping procedure. Therefore, the measurement for Utility Value (comprising of price, service convenience and quality), Hedonic Value (comprising of brand awareness and brand meaning), Relational Value (comprising of trust, bonding, empathy and mutual dependence), Brand Relationship Quality (comprising of commitment, passion and liking) and Brand Resonance (comprising of loyalty, active engagement and sense of community) are significant and aligned with the theory described in the literature review. 
Table 4: Measurement Model Quality

\begin{tabular}{|c|c|c|c|c|c|c|c|}
\hline \multirow{2}{*}{$\begin{array}{c}\text { Construct } \\
\text { (Higher order) }\end{array}$} & \multirow{2}{*}{$\begin{array}{c}\text { Items } \\
\text { (Lower Order) }\end{array}$} & \multirow{2}{*}{$\begin{array}{c}\text { Convergent } \\
\text { Path }\end{array}$} & \multicolumn{2}{|c|}{ Collinearity } & \multicolumn{3}{|c|}{ Total effect } \\
\hline & & & Tolerance & VIF & $\begin{array}{c}\text { Sample } \\
\text { Mean }\end{array}$ & T Stat. & Sig. \\
\hline \multirow[t]{3}{*}{ Utility Value } & Price & 0.788 & 0.763 & 1.311 & 0.444 & 27.366 & 0.003 \\
\hline & Service convenience & 0.756 & 0.706 & 1.417 & 0.339 & 24.094 & 0.000 \\
\hline & Service quality & 0.834 & 0.687 & 1.455 & 0.471 & 28.977 & 0.000 \\
\hline \multirow[t]{2}{*}{ Hedonic Value } & Brand awareness & 0.889 & 0.646 & 1.549 & 0.549 & 46.137 & 0.000 \\
\hline & Brand meaning & 0.898 & 0.646 & 1.549 & 0.571 & 51.988 & 0.031 \\
\hline \multirow[t]{4}{*}{ Relational Value } & Trust & 0.819 & 0.630 & 1.590 & 0.378 & 35.945 & 0.000 \\
\hline & Bonding & 0.726 & 0.690 & 1.440 & 0.268 & 24.361 & 0.000 \\
\hline & Empathy & 0.773 & 0.630 & 1.600 & 0.282 & 28.510 & 0.010 \\
\hline & Mutual Dependence & 0.816 & 0.590 & 1.690 & 0.340 & 35.153 & 0.040 \\
\hline
\end{tabular}

Table 5: Measurement Model Quality (con't)

\begin{tabular}{|c|c|c|c|c|c|c|c|}
\hline \multirow{2}{*}{$\begin{array}{c}\text { Construct } \\
\text { (Higher order) }\end{array}$} & \multirow{2}{*}{$\begin{array}{c}\text { Items } \\
\text { (Lower Order) }\end{array}$} & \multirow{2}{*}{$\begin{array}{c}\text { Convergent } \\
\text { Path }\end{array}$} & \multicolumn{2}{|c|}{ Collinearity } & \multicolumn{3}{|c|}{ Total effect } \\
\hline & & & Tolerance & VIF & $\begin{array}{c}\text { Sample } \\
\text { Mean }\end{array}$ & T Stat. & Sig. \\
\hline Brand & Commitment & 0.885 & 0.504 & 1.984 & 0.422 & 46.844 & 0.00 \\
\hline Relationship & Passion & 0.862 & 0.549 & 1.82 & 0.401 & 45.518 & 0.00 \\
\hline Quality & Liking & 0.831 & 0.561 & 1.783 & 0.338 & 39.933 & 0.00 \\
\hline \multirow[t]{3}{*}{ Brand Resonance } & Loyalty & 0.899 & 0.553 & 1.807 & 0.504 & 39.573 & 0.00 \\
\hline & Active engagement & 0.807 & 0.625 & 1.6 & 0.345 & 29.304 & 0.00 \\
\hline & Sense of community & 0.798 & 0.637 & 1.57 & 0.335 & 24.92 & 0.00 \\
\hline
\end{tabular}

\subsection{Hypothesis Testing (Structural Model)}

The study was conducted using the Multiple Regression tests via SmartPLS software to further understand how customer value influences customer brand relationship stickiness. Referring to Table 6 , the results for the path and coefficient determination ( $\mathrm{R}^{2}$ value) of multiple constructs consisting of utility, hedonic and relational values towards brand relationship quality and brand resonance are significant. However, utility and hedonic values are moderate towards influencing customer's brand relationship stickiness where its path coefficient is less than 0.7 for both brand relationship quality and brand resonance. On the other hand, relational value shows better results towards influencing customer's brand relationship stickiness. Its path coefficient exceeds 0.7, which can be considered as a high contribution in terms of change in the endogenous construct of brand relationship quality and brand resonance (Hair et al., 2014; Henseler et al., 2009).

To examine hypotheses 1 and 2, the study employed PLS bootstrapping procedure to compute the t-value. Table 6 shows the t-value of the path between the multiple construct of customer value and brand relationship quality or $\mathrm{H} 1$ is 4.20 (utility value), 3.00 (hedonic value) and 17.69 (relational value). While, for $\mathrm{H} 2$, the t-value of the path between the multiple construct of customer value and brand resonance is 6.33 (utility value), 4.34 (hedonic value) and 11.31 (relational value). Therefore, due to all t-value results are greater than the probability error value of 1.96 (significance level $=5 \%$ ) and 2.57 (significance level = 1\%) as suggested by Hair et al. (2014), the study comfortably concludes that hypotheses 1 and 2 are supported. The results are also consistent with the Social Exchange Theory assumption, which suggests customers depend on multiple benefits or values as the stimulus to influence their exchange interactions and behaviours with product/service or brand. 
Table 6: Utility, Hedonic and Relational Value Path Coefficient toward Brand Relationship Quality (H1) and Brand Resonance (H2)

\begin{tabular}{llcccccc}
\hline \hline \multicolumn{1}{c}{ Path Model } & $\begin{array}{c}\text { Path } \\
\text { Coefficient }\end{array}$ & $\begin{array}{c}\text { R } \\
\text { Square }\end{array}$ & $\begin{array}{c}\text { Original } \\
\text { Sample }\end{array}$ & $\begin{array}{c}\text { Standard } \\
\text { Error }\end{array}$ & T Statistics & Hypothesis \\
\hline H1 & Utility value to BRQ & 0.6098 & & 0.1531 & 0.0365 & 4.2000 & Accept \\
& Hedonic value to BRQ & 0.5989 & 0.6287 & 0.1144 & 0.0381 & 3.0046 & Accept \\
& Relational value to BRQ & 0.7758 & & 0.6017 & 0.034 & 17.6926 & Accept \\
\hline H2 & Utility value to BR & 0.6202 & & 0.2305 & 0.0364 & 6.3295 & Accept \\
& Hedonic value to BR & 0.5981 & 0.5564 & 0.1651 & 0.038 & 4.346 & Accept \\
& Relational value to BR & 0.7085 & & 0.4441 & 0.0393 & 11.3129 & Accept \\
\hline \hline
\end{tabular}

The study investigated the magnitude change or effect size as resulted from the occurrence of the relational value towards brand relationship quality and brand resonance prediction to address customer brand stickiness issues ( $\mathrm{H} 3$ and $\mathrm{H} 4$ ). In assessing the magnitude change, the study compared the result of $\mathrm{R}^{2}$ relational value included model (Model 1) and the $\mathrm{R}^{2}$ relational value excluded model (Model 2) as illustrated in Figure 2. Data from PLS Bootstrapping as exhibited in Table 7 shows that the effect size $\left(\mathrm{f}^{2}\right)$ of relational value in the proposed models is significant where $\mathrm{p}<0.0005$. The results from individual perspective of customer shows that relational value has a large effect $\left(\mathrm{f}^{2}=0.454\right)$ on the brand relationship quality prediction, and medium effect $\left(\mathrm{f}^{2}=0.203\right)$ towards brand resonance's prediction compared to utility $\left(f^{2}=0.181 ; 0.214\right)$ and hedonic value $\left(f^{2}=0.177 ; 0.185\right)$ respectively.

Figure 2: Relational Value Effect towards Customer Brand Relationship Stickiness

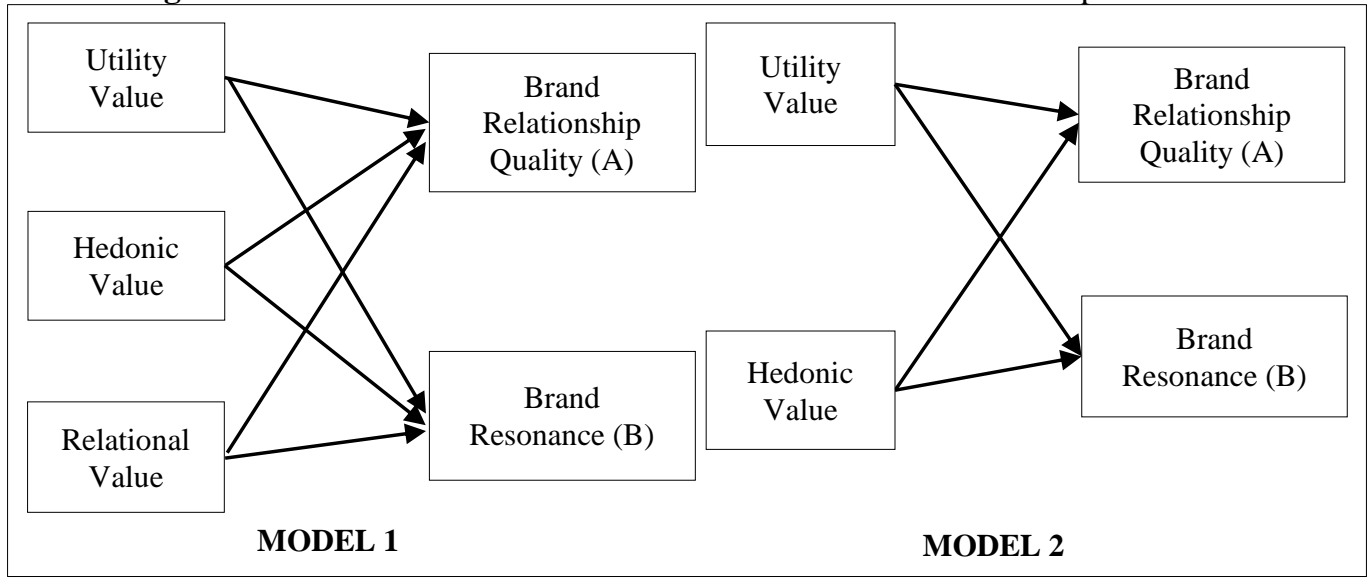

The study used the calculation of $\mathrm{f}^{2}$ as suggested by (Hair et al., 2014), where the value of $\mathrm{R}^{2}$ included and $\mathrm{R}^{2}$ excluded differences divided by the residual value of $\mathrm{R}^{2}$ included to compute the effect size differences between model 1 and model 2. In detail, for $\mathrm{H} 3$, the result shows that the inclusion model of relational value (model 1 ) has a large effect $\left(f^{2}=0.44\right)$ on the prediction towards brand relationship quality compared to the antecedents model without a relational value dimension (model 2). Meanwhile, for H4, the inclusion model of relational value (Model 1) illustrates a medium effect $\left(\mathrm{f}^{2}=0.198\right)$ on the prediction towards brand resonance compared with the antecedents model without a relational value dimension (Model 2). In principal, hypotheses 3 and 4 are significant because both reached statistical significance of $\mathrm{p}<0.0005$. Therefore, this study validates the impact of relational value in enhancing the customer brand relationship stickiness as claimed by Klaus and Maklan (2007) and Merz et al. (2009). 
Table 7: Relational Value Effect Size Summary

\begin{tabular}{|c|c|c|c|c|c|c|}
\hline Total Effects & $\mathbf{f}^{2}$ & $\begin{array}{c}\mathbf{P} \\
\text { Values } \\
\end{array}$ & R Square & T Statistics & $\begin{array}{c}\mathbf{P} \\
\text { Values } \\
\end{array}$ & $\begin{array}{c}\text { Effect Size } \\
\left(\mathbf{f}^{\mathbf{2}} \text { Stuctural Model }\right) \\
\end{array}$ \\
\hline \multicolumn{7}{|l|}{ Model 1a } \\
\hline Utility>Brand Relationship Quality & 0.034 & 0.000 & \multirow{4}{*}{0.629} & \multirow{4}{*}{25.376} & \multirow{4}{*}{0.000} & \multirow{3}{*}{ M1a-M2a } \\
\hline Hedonic>Brand Relationship Quality & 0.018 & 0.003 & & & & \\
\hline Relational>Brand Relationship Quality & 0.454 & 0.000 & & & & \\
\hline Model 2a & & & & & & \multirow[t]{3}{*}{0.44 (large effect $>0.35$ ) } \\
\hline Utility>Brand Relationship Quality & 0.181 & 0.000 & \multirow{2}{*}{0.466} & \multirow{2}{*}{15.448} & \multirow{2}{*}{0.000} & \\
\hline Hedonic $>$ Brand Relationship Quality & 0.177 & 0.000 & & & & \\
\hline \multicolumn{7}{|l|}{ Model 1b } \\
\hline Utility $>$ Brand Resonance & 0.063 & 0.000 & \multirow{4}{*}{0.570} & \multirow{4}{*}{19.546} & \multirow{4}{*}{0.000} & \multirow{5}{*}{$\begin{array}{l}\text { nedium effect } \\
>0.15)\end{array}$} \\
\hline Hedonic $>$ Brand Resonance & 0.036 & 0.000 & & & & \\
\hline Relational $>$ Brand Resonance & 0.203 & 0.000 & & & & \\
\hline Model 2b & & & & & & \\
\hline Utility $>$ Brand Resonance & 0.214 & 0.000 & \multirow{2}{*}{0.485} & \multirow{2}{*}{16.407} & \multirow{2}{*}{0.000} & \\
\hline Hedonic>Brand Resonance & 0.185 & 0.000 & & & & $\mathrm{H} 4=$ Accepted \\
\hline
\end{tabular}

\section{DISCUSSION AND CONCLUSION}

The study has taken a step further by looking at the holistic concept of customer values proposed by Rust et al. (2004) in terms of utilitarian, hedonic and relational value in the Malaysian public university setting. Investigating customer value from students' perspectives is essential to have a holistic view about the student learning experience and able to explain the motivation of their reciprocal behavior towards the institutions. The study begins by looking at its predictive ability towards customer brand relationship stickiness (brand relationship quality and brand resonance). The finding validates the assumption outlined by the Social Exchange Theory (SET) in which the formation of psychological ties and customer behavioural response depends on the multiple stimuli of value that influence the exchange interaction. The significant impact of students' value towards their brand stickiness with the institution had ratified the importance of customer orientation in the higher education sector. This is also consistent with Sheth, Sethia and Srinivas (2011) and Sharizal and Norjaya (2012), who claimed that customer value is an important antecedent of customer assessment of products or service experience. Assessing the various aspects of customer value may help brand managers to know the key information about what to be focused in order to develop a good relationship with customers.

In contrast, in the context of higher education, the effect of student value dimensions as the customer varies. This is because customers compare few values as the basis of their decision to remain in the relationship (Zafirovski, 2005). Particularly, this study provides an evidence of how relational value affects the "stickiness" of student brand relationship towards the institution, compared to utility and hedonic value provided by the institution. The results show that utility and hedonic value have limitations in differentiating how customers perceive and evaluate brands beyond the monetary evaluation (Eiriz \& Wilson, 2006: Brodies et al., 2006), and also has not fully captured the broader description of service cocreation concept (Khan, 2010; Brodies et al., 2013). The finding also supports Lusch and Vargo (2006), Grönroos and Voima (2013) and Zhang et al., (2014), who suggested that to form and grow the relationship stickiness, each party in the exchange must create and deliver values to the other beyond its physical/utilitarian aspects of the product or service. Thus, the study provides an evidence of considering relational values as the additional strategy in service brand process that enables an organization to gain high "stickiness" relationship nature of their customer. 
On the other hand, validating the role of customer value and exploring the concept of customer brand relationship stickiness provides an alternative and creative description of brand development in the service context, especially in the higher learning service. According to Chapleo (2015), higher learning institution or university branding is inherently complex and the application of such approaches may be over simplistic. A shift to the new brand strategy that emphasizes relational value may help the universities to enjoy and sustain their brand image from the perspective of their customers. It is evident that the path or predictive ability towards brand relationship quality, brand resonance, and even the overall relationship structure, were among the top compared with the other two values. Such a phenomenon is also consistent with the service experience based economy perspective, which states that the relational value that stems from the social interaction domain plays a vital role in "gluing" the customers to the brand and enhancing the "stickiness" of the relationship.

While the findings of this study provide a number of theoretical and practical implications, it is also important to acknowledge the possible limitations and future studies that are associated with it. Basically, this study is limited to three antecedents which are utility, hedonic and relational values that are underpinned by the Customer Equity Theory as proposed by Rust et al., (2004). However, it would be worthwhile for future research to incorporate other antecedents, such as cultural value and ethical value, which would provide interesting insights into how the customer brand relationship is affected by the different cultures of a nation (e.g. individualism, collectivism, power distance). By incorporating other variables into the model, it is hoped to furnish a better understanding concerning the concept of customer perceived value in the modern economic exchange context. Apart from that, the context of this study was also limited to only public universities, and it may be worthwhile to conduct more research concerning other service categories, such as hotels, transportation, public service and communication. Hence, it is important to examine how the customer brand relationship concept differs or similar across service categories and able to generate a more solid description about customer brand relationship concept in the service context.

Summing up, it can be said that this study has provided some theoretical and managerial guidance for capitalizing the potential of the customer brand relationship concept in the service area. Underpinned by the Social Exchange Theory, customers in the service brand context establish their relationship stickiness with the brand, which is largely dependent on the motivation of an exchange of relational values. This indicates that the crucial phase of the branding process in the service organization is to make sure relational value such as trust, bonding, empathy and mutual dependence become the key elements in the overall service experience before they can expect greater bonding and a favorable response from their customer. In this respect, customer relationship orientation is a feasible and practical strategy to exercise firm branding. Thus, the present study is hoped to provide immense contributions to the knowledge of customer brand relationship in the service area in line with the recent development.

\section{ACKNOWLEDGEMENT}

This work was supported by UNIMAS's Special Grant Scheme (F01/SpGS/1419/16/20)

\section{REFERENCES}

Aaker, J. (1997). Dimensions of brand personality. Journal of Consumer Research, 34(3), 347-356. Aggarwal, P. (2004). The effects of brand relationship norms on consumer attitudes and behavior. Journal of Consumer Research, 31(1), 87-101. 
Alves, H., \& Raposo, M. (2007). Conceptual model of student satisfaction in higher education. Total Quality Management, 18(5), 571-588.

Balwin, G., \& James, R. (2000). The market in Australian higher education and the concept of student as informed consumer. Journal of Higher Education Policy and Management, 22(2), 139-148.

Becker-Olsen, K., \& Hill, R. (2006). The impact of sponsor fit on brand equity: The case of nonprofit service providers. Journal of Service Research, 9(1), 73-83.

Berry, L. L. (2000). Cultivating Service Brand Equity. Journal of the Academy of Marketing Science, $28(1), 128-137$.

Blackston, M., \& Lebar, E. (2015). Constructing consumer-brand relationships to better market and build business. In S. Fournier, M. Breazeale \& J. Avery (Eds.), Strong Brands, Strong Relationships (pp. 376-392). New York: Taylor \& Francis

Breivik, E., \& Thorbjørnsen, H. (2008). Consumer brand relationships: an investigation of two alternative models. Journal of Academy Marketing Science, 36(4), 443-472.

Brodie, R. J., Glynn, M. S., \& Little, V. (2006). The service brand and the service-dominant logic: missing fundamental premise or the need for stronger theory? Marketing Theory, 6(3), 363-379.

Brodie, R. J., Ilic, A., Juric, B., \& Hollebeek, L. (2013). Consumer engagement in a virtual brand community: An exploratory analysis. Journal of Business Research, 66(1), 105-114.

Brown, R. M., \& Mazzarol, T. W. (2009). The importance of institutional image to student satisfaction and loyalty within higher education. Higher Education, 58(1), 81-95.

Broyles, S., Schumann, D., \& Leingpibul, T. (2009). Examining brand equity antecedents/consequence relationships. The Journal of Marketing Theory and Practice, 17(2), 145-162.

Chapleo, C. (2011). Exploring rationales for branding a university: Should we be seeking to measure branding in UK universities? Journal of Brand Management, 18(6), 411-422.

Chapleo, C. (2015). An exploration of branding approaches in UK universities. International Journal of Nonprofit and Voluntary Sector Marketing, 20(1), 1-11.

Chaudhuri, A., \& Holbrook, M. (2001). The chain of effects from brand trust and brand affect to brand performance: The role of brand loyalty. Journal of Marketing, 65(2), 81-93.

Chin, W. W. (1998). The Partial Least Squares Approach for Structural Equation Modeling, In G. A. Marcoulides (Eds.), Modern Methods for Business Research (pp. 295- 336). New York: Lawrence Erlbaum Associates.

Chiu, C. M., Hsu, M. H., Lai, H., \& Chang, C. M. (2012). Re-examining the influence of trust on online repeat purchase intention: The moderating role of habit and its antecedents. Decision Support Systems, 53(4), 835-845.

Chiu, C.-M., Wang, E. T., Fang, Y.-H. \& Huang, H.-Y. (2014). Understanding customers' repeat purchase intentions in $\mathrm{B} 2 \mathrm{C}$ e-commerce: the roles of utilitarian value, hedonic value and perceived risk. Information Systems Journal, 22(4), 85-114.

Cook, K. S., \& Emerson, R. M. (1987). Social exchange theory. Newbury Park, CA: Sage.

Cronin, J. J., Brady, M., \& Hult, G. (2000). Assessing the effects of quality, value and customer satisfaction on consumer behavioral intentions in service environments. Journal of Retailing, 76(2), 193-218.

Dowling, G. (2002). Customer relationship management: In B2C markets, often less is more. California Management Review, 44(3), 87-104.

Eiriz, V., \& Wilson, D. (2006). Research in relationship marketing: antecedents, traditions and integration. European Journal of Marketing, 40(3/4), 275-291.

Fournier, S. (1998). Consumers and their brands: developing relationship theory in consumer research. Journal of Consumer Research, 24(4), 343-373.

Fournier, S., Solomon, M. R., \& Englis, B. G. (2008). When brands resonate, In B. H. Schmitt \& D. L. Rogers (Eds.), Handbook on Brand And Experience Management (pp. 35-57). Northampton, MA: Edward Elgar. 
Fullerton, G. (2005). How commitment both enables and undermines marketing relationships. European Journal of Marketing, 39(11/12), 1372-1388.

Gallarza, M. G., Gil-Saura, I., \& Holbrook, M. B. (2011). The value of value: further excursions on the meaning and role of customer value. Journal of consumer behaviour, 10(4), 179-191.

Gibbs, P. (2002). From the invisible hand to the invisible handshake: marketing higher education. Research in Post-Compulsory Education, 7(3), 325-338.

Goi, C. L., \& Goi, M. T. (2009). Rebranding of higher educational institutions in Malaysia. International Journal of Business and Management, 4(9), 170-177.

Grönroos, C., \& Gummerus, J. (2014). The service revolution and its marketing implications: Service logic vs service-dominant logic. Managing Service Quality, 24(3), 206-229.

Grönroos, C., \& Voima, P. (2013). Critical service logic: making sense of value creation and co-creation. Journal of the Academy of Marketing Science, 41(2), 133-150.

Hair, J., Black, W., Babin, B. \& Anderson, R. (2010). Multivariate Data Analysis: A Global Perspective. New Jersey: Pearson Education.

Hair, J., Hult, G. T., Ringle, C., \& Sarstedt, M. (2014). A Primer on Partial Least Squares Structural Equation Modeling (PLS-SEM). California: Sage Publication.

Hemsley-Brown, J., \& Goonawardana, S. (2007). Brand harmonization on the international higher education market. Journal of Business research, 60(9), 942-948.

Hemsley-Brown, J., \& Oplatka, I. (2006). Universities in a competitive global marketplace: a systematic review of the literature on higher education marketing. International Journal of Public Sector Management, 19(4), 316-338.

Henseler, J., Ringle, C. M., \& Sinkovics, S. S. (2009). The use of partial least squares path modeling in international marketing. Advances in International Marketing, 20(1), 277-319

Hess, L., \& Story, J. (2005). Trust-based commitment: Multidimensional consumer-brand relationship. Journal of Consumer Marketing, 22(6), 313-322.

Hinde, R. A. (1995). A suggested structure for a science of relationships. Personal Relationships, 2(1),115.

Hu, X., Tetrick, L., \& Shore, L. (2011). Understanding reciprocity in organizations: a US-China comparison. Journal of Managerial Psychology, 26(7), 528-548.

Huang, C. C., Yen, S. W., Liu, C. Y., \& Chang, T. P. (2014). The relationship among brand equity, customer satisfaction, and brand resonance to repurchase intention of cultural and creative industries in Taiwan. The International Journal of Organizational Innovation, 6(3),106-120.

Judson, K., Aurand, T., \& Gorchels, L. (2006). Building a university brand from within: A comparison of coaches' perspectives of internal branding. Journal of Marketing for Higher Education, 16(1), 97114.

Keller, K. L. (2001). Building Customer-Based Brand Equity: A Blueprint for Creating Strong Brands. Cambridge: Marketing Science Institute.

Keller, K. L. (2008). Strategic Brand Management: Building Measuring and Managing Brand Equity ( $3^{\text {rd }}$ Ed.) Upper Saddle River: NJ:Prentice-Hall.

Khalifa, M., Limayem, M., \& Liu, V. (2002). Online consumer stickiness: a longitudinal study. Journal of Global Information Management, 10(3), 1-15.

Khan, N. (2010). Functional and relational value influence on commitment and future intention: The case of banking industry. The Journal of International Social Research, 3(10), 376-391.

Kim, K., Park, J., \& Kim, J. (2014). Consumer-brand relationship quality: When and how it helps brand extensions. Journal of Business Research, 67(4), 591-597.

Klassen, M. (2002). Relationship marketing on the Internet: The case of top- and lower-ranked universities and colleges. Journal of Retailing and Consumer Services, 9(2), 81-85. 
Klaus, P., \& Maklan, S. (2007). The role of brands in a service-dominated world. Brand Management, 15(2), 115-122.

Konovsky, M., \& Pugh, S. (1994). Citizenship behavior and social exchange. Academy of Management Journal, 37(3), 656-669.

Kuhn, K.-A., Alpert, F., \& Pope, N. (2008). An application of Keller's brand equity model in a B2B context. Qualitative Market Research: An International Journal, 11(1), 40 - 58.

Kumar. S. R., Lassar, W. M., \& Butaney, G. T (2014). The mediating impact of stickiness and loyalty on word-of-mouth promotion of retail websites: A consumer perspective, European Journal of Marketing, 48(9/10), $1828-1849$.

Lambe, C. J., Wittmann, C. M., \& Spekman, R. E. (2001). Social exchange theory and research on business-to-business relational exchange. Journal of Business-to-Business Marketing, 8(3), 1-36.

Leone, R. P., Rao, V. R., Keller, K. L., Luo, A. M., McAlister, L., \& Srivastava, R. (2006). Linking brand equity to customer equity. Journal of Service Research, 9(2), 125-138.

Li, D., Browne, G. J., \& Wetherbe, J. C. (2006). Why Do Internet Users Stick with a Specific Web Site? A Relationship Perspective. International Journal of Electronic Commerce, 10(4), 105-141.

Lusch, R. F., \& Vargo, S. L. (2006). Service-dominant logic: Reactions, reflections and refinements. Marketing Theory September, 6(3), 281-288.

Melewar, T. C., \& Akel, S. (2006). The role of corporate identity in the higher education sector: A case study. Corporate Communications: An International Journal, 10(1), 41-57.

Merz, M., He, Y., \& Vargo, S. (2009). The evolving brand logic: A service-dominant logic perspective. Journal of the Academic Marketing Science, 37(3), 328-344.

MoHE. (2010). Statistics of Higher Education of Malaysia. Planning and Research Division. Putrajaya, Malaysia: Ministry of Higher Education, Malaysia.

Morgan, R. M., \& Hunt, S. D. (1994). The commitment-trust theory of relationship marketing. The journal of marketing, 58(3), 20-38.

Norbani, C.-H., \& Sharizal, H. (2007). Brand equity, customer satisfaction \& loyalty: Malaysian banking sector. International Review of Business Research Paper, 3(5), 123-133.

Norjaya, M. Y., \& Norzalita, A. A. (2010). Analyzing the brand equity and resonance of banking services: Malaysian consumer perspective. International Journal of Marketing Studies, 2(2), 180-189.

Nyffenegger, B., Krohmer, H., Hoyer, W. D., \& Malaer, W. (2015). Service brand relationship quality hot or cold? Journal of Service Research, 18(1), 90 - 106.

O'Cass, A., \& Grace, D. (2004). Exploring consumer experiences with a service brand. Journal of Product \& Brand Management, 13(4), 257-268.

Oh, L. B., \& Teo, H. H. (2010). Consumer value co-creation in a hybrid commerce service-delivery system. International Journal of Electronic Commerce, 14(3), 35 - 62.

Parasuraman, A., Zeithaml, V. A., \& Berry, L. L. (1985). A conceptual model of service quality and its implications for future research. Journal of Marketing, 49(4), 41-50.

Polites, G. L., Williams, C. K., Karahanna, E., \& Seligman, L. (2012). A Theoretical Framework for Consumer E-Satisfaction and Site Stickiness: An Evaluation in the Context of Online Hotel Reservations. Journal of Organizational Computing and Electronic Commerce, 22(1), 1-37.

Prahalad, C. K., \& Ramaswamy, V. (2004). Co-creation experiences: The next practice in value creation. Journal of interactive marketing, 18(3), 5-14.

Rauyruen, P., \& Miller, K. (2007). Relationship quality as a predictor of b2b customer loyalty. Journal of Business Research, 60(1), 21-31.

Roberts, K., Varki, S., \& Brodie, R. (2003), Measuring the quality of relationships in consumer services: An empirical study. European Journal of Marketing, 37(1/2), 166-196.

Rust, R. T., Lemon, K. N., \& Zeithaml, V. A. (2004). Return on marketing: Using customer equity to focus marketing strategy. Journal of Marketing, 68, 109-127. 
Sánchez, J., Callarisa, L., Rodríguez, R., \& Moliner, M. (2006). Perceived value of the purchase of a tourism product. Tourism Management, 27(3), 394-409.

Seiders, K., Voss, G., Godfrey, A., \& Grewal, D. (2007). SERVCON: Development and validation of a multidimensional service convenience scale. Journal of the Academy Marketing Science, 35(1), 144156.

Sharizal, H., \& Norjaya, M. Y. (2012). Exploring the mediating effect of brand relationship quality in the service brand equity and brand resonance linkage. Jurnal Pengurusan, 36(12), 123-134.

Sheth, J. N., Newman, B. I., \& Gross, B. L. (1991). Why we buy what we buy: A theory of consumption values. Journal of business research, 22(2), 159-170.

Sheth, J., Sethia, N., \& Srinivas, S. (2011). Mindful consumption: A customer-centric approach to sustainability. Journal of the Academy of Marketing Science, 39(1), 21-39.

Shimp, T., \& Madden, T. (1988). Consumer-object relations: A conceptual framework based analogously on Sternberg's triangular theory of love. Advances in Consumer Research, 15, 163-168.

Sloot, L. M., Verhoef, P. C., \& Franses, P. H. (2005). The impact of brand equity and the hedonic level of products on consumer stock-out reactions. Journal of Retailing, 81(1), 15-34.

Smit, E., Bronner, F., \& Tolboom, M. (2007). Brand relationship quality and its value for personal contact. Journal of Business Research, 60(6), 627-633.

Sternberg, R. J. (1986). A triangular theory of love. Psychology Review, 93(2), 119-135.

Story, J., \& Hess, J. (2006). Segmenting customer-brand relations: Beyond personal relationship metaphor. Journal of Consumer Marketing, 23(7), 406-413.

Sweeney, J. C., \& Chew, M. (2002). Understanding customer-service brand relationship: A case study approach. Australasian Marketing Journal, 10(2), 26-43.

Tabachnick, B. G., \& Fidell, L. S. (2007). Multivariate analysis of variance and covariance. In B. G. Tabachnick \& L. S. Fidell (Eds.), Using multivariate statistics (pp. 371-435). Boston: Allyn and Bacon.

Teh, G. M., \& Aliah Hanim, M. (2011). Impact of brand meaning on brand equity of higher educational institutions in Malaysia. World Journal of Management, 3(2), 218-228.

Ulaga, W., \& Eggert, A. (2005). Relationship value in business markets: The construct and its dimensions. Journal of Business-to-Business Marketing, 12(1), 73-99.

Vargo, S. L., \& Lusch, R. F. (2004). Evolving to a new dominant logic for marketing. Journal of Marketing, 68(1), 1-17.

Vargo, S. L., \& Lusch, R. F. (2008). Service-dominant logic: Continuing the evolution. Journal of Academy of Marketing Science, 36(1), 1-10.

Verghese, A., \& Kamalanabhan, T. J. (2015). Attributes influencing information search for College choice: An exploratory study. International Journal of Business Innovation and Research, 9(1), 34-51.

Vogel, V., Evanschitzky, H., \& Ramaseshan, B. (2008). Customer equity drivers and future sales. Journal of Marketing, 72(6), 98-108.

Wæraas, A., \& Solbakk, M. N. (2009). Defining the essence of a university: Lessons from higher education branding. Higher Education, 57(4), 449-462.

Wojciszke, B., Abele, A., \& Baryla, W. (2009). Two dimensions of interpersonal attitudes: Liking depends on communion, respect depends on agency. European Journal of Social Psychology, 39(6), 973990.

Wu, L. (2011). Beyond satisfaction: The relative importance of locational convenience, interpersonal relationships, and commitment across service types. Managing Service Quality, 21(3), 240-263.

Yau, O., McFetridge, P. R., Chow, R. P., Lee, J. S., Sin, L. Y., \& Tse, A. C. (2000). Is relationship marketing for everyone? European Journal of Marketing, 34(9/10), 1111 - 1127. 
Yim, C., Tse, D., \& Chan, K. (2008). Strengthening customer loyalty through intimacy and passion: Roles of customer-firm affection and customer-staff relationships in services. Journal of Marketing Research, 45(6), 741-756.

Zafirovski, M. (2005). Social exchange theory under scrutiny: A positive critique of its economicbehaviorist formulations. Electronic Journal of Sociology, 1-40.

Zainuddin, Z., Rosmimah, M. R., \& Norzaidi, M. D. (2011). The influence of market orientation on the commitment, trust and relational norms in the education context. African Journal of Business Management, 5(22), 8875-8890.

Zeithaml, V.A. (1988). Consumer perception of price, quality and value: A means-end-model and synthesis of evidence. The Journal of Marketing, 52(3), 2-22.

Zhang, S., Doorn, J. V., \& Leeflang, P. S. (2014). Does the importance of value, brand and relationship equity for customer loyalty differ between Eastern and Western cultures?. International Business Review, 23(1), 284-292.

\section{APPENDICES}

Appendix 1: Enrolment of Public HEI by Area of Study (2010)

\begin{tabular}{lcccc}
\hline \hline \multicolumn{1}{c}{ Area } & PhD & Master & Total & \% \\
\hline Education & 2413 & 7719 & 10132 & 15.03 \\
Art and Humanities & 1622 & 4892 & 6514 & 9.67 \\
Social Sciences, Business, Law & 5143 & 12689 & 17832 & 26.46 \\
Science, Mathematics, Computer & 3417 & 7154 & 10571 & 15.69 \\
Engineering,Manufacturing, Construction & 3563 & 9788 & 13351 & 19.81 \\
Agriculture, Veterinary & 246 & 1211 & 1457 & 2.16 \\
Health, Welfare & 1112 & 5156 & 6268 & 9.30 \\
Services & 202 & 1067 & 1269 & 1.88 \\
\hline \hline
\end{tabular}

Source: Planning and Research Division, MoHE (2010).

Appendix 2: Enrolment of Public HEI 2010

\begin{tabular}{ccccccccc}
\hline \hline Public HEI & PhD & Master & Total & & Public HEI & PhD & Master & Total \\
\cline { 1 - 2 } \cline { 7 - 8 } UPM & 2878 & 7560 & 10438 & & UTHM & 158 & 625 & 783 \\
UM & 2708 & 7210 & 9918 & & UMT & 120 & 423 & 543 \\
UKM & 2883 & 6504 & 9387 & & UTeM & 51 & 391 & 442 \\
USM & 2718 & 5472 & 8190 & & UniMAP & 98 & 236 & 334 \\
UTM & 2073 & 4958 & 7031 & & USIM & 138 & 163 & 301 \\
UUM & 1306 & 4911 & 6217 & UMP & 97 & 162 & 259 \\
UiTM & 842 & 5298 & 6140 & & UniSZA & 26 & 91 & 117 \\
UIAM & 967 & 2638 & 3605 & & UMK & 21 & 56 & 77 \\
UPSI & 260 & 1554 & 1814 & & UPNM & 14 & 17 & 31 \\
UMS & 244 & 649 & 893 & & Total & $\mathbf{1 7 7 1 8}$ & $\mathbf{4 9 6 7 6}$ & $\mathbf{1 1 7 0 7 0}$ \\
UNIMAS & 116 & 758 & 874 & & & & & \\
\hline \hline
\end{tabular}

Source: Planning and Research Division, MoHE (2010). 